\title{
A resource management model based on community forestry in the Philippines
}

Yuta Harago Meiji Gakuin University, The Faculty of Economics, 1-2-37 Shirokanedai, Minatoku, Tokyo 108-0071, Japan

\begin{abstract}
A Resource Management Model (RMM) has been conceived and designed to effectively organize and prioritize various management agendas necessary to pursue the successful implementation of community forestry. The RMM consists of two management components: 1) Management Capital and 2) Natural Resource Management. The Management Capital is capitalized by three fundamental components; a) Human Resource Development, b) Livelihood Development and c) Basic Infrastructure. It constitutes a principal management agent in effectively mobilizing activities concerning the Natural Resource Management.

Firstly, the practice of community forestry systems in the Philippines was reviewed and analysed using field surveys. It was found that in spite of the Philippine government's emphasis on introducing policy supporting agroforestry systems as a land tenure as well as sustainable land use strategy, marginal economic benefits have so far been gained from such initiatives. Secondly, using such findings, as well as identified interests and constraints, necessary management elements were classified and incorporated into the RMM, enabling the identification and prioritization of requirements for the successful development of community forestry. Community forestry will become effective and sustainable only when various actions concerning the Natural Resource Management are pursued after the satisfactory development of the Management Capital.
\end{abstract}

Key words: Community forestry, Community-Based Forest Management (CBFM), Resource Management Model(RMM), Management Capital, Human Resource Development

\section{INTRODUCTION}

Community forestry has been adopted as a sustainable resource management strategy in many tropical countries in Asia, such as India, Sri Lanka, Nepal, Myanmar, Thailand, Indonesia and the Philippines (Poffenberger, 1990 and 1997. Lynch and Talbott, 1995; Poffenberger, et al. 1996; Victor, et al. 1998. World Bank. 2000). In many cases community forestry has been introduced in an attempt to reverse serious damages that industrial commercial logging caused through the marked reduction of forest resources. In the Philippines, 27 million ha (90\%) of the country was endowed with forest coverage during the 1600s. The forest coverage was reduced to 21 million ha (70\%) by 1900, and was diminished to a mere 5.4 million ha (18\%) by 1997. This reduction occurred largely due to massive commercial logging during the 1960s and 1970s. Today the country has become one of the global leaders in promoting, as well as putting into practice, the concept of community forestry by supporting relevant legal and administrative instruments (Talisayon, 1991; Bisson, 1997; Mickelwait, 1999; ESSC. 1999; Nagano, Hayama and Seki, 2000).

Meanwhile, initiatives towards introducing community forestry have often brought about mixed results. Reckless attempts to restore degraded environments with original vegetative cover by mobilizing the local population as contracted labor have often failed to bring about expected results, once external financial and technical assistance were exhausted. Restoration initiatives imposed by the local population often discontinue due to the inability to generate and cover fixed maintenance costs required for the established plantations. In the light of this, the need is obvious for developing an effective Resource Management Model (RMM) for the fulfillment of appropriate natural resource management including community forestry.

\section{METHODS}

Firstly, community forestry in the Philippines was reviewed and analysed, from which the RMM was conceived and designed. A concrete design and application method of the RMM was developed during the undertaking of The Master Plan Study for Watershed Management in the Upper Magat and Cagayan River Basin ${ }^{1)}$. The study area encompassed the upper

1) The Study was conducted by the Japan International Cooperation Agency (JICA) under a technical cooperation agreement between the governments of Japan and the Philippines, in which the author participated during May 2001 - February 2002 as an expert on community forestry. The data used in this thesis was collected during the undertaking of the study, and organized for this study under authorization from JICA. 
watershed of the Magat and Cagayan rivers in Luzon Island, the most important river basin for the Philippine economy in terms of crop productions (Figure 1).

Secondly, focusing on the study area, an analysis was made on the Community-Based Forest Management (CBFM) program. Thirdly, an instrumental review on the program was undertaken following the identification of participation interests and constraints with the field survey on selected CBFM sites ${ }^{2)}$. The survey included questions on land tenure, land use, as well as revenue analysis on agricultural, pastoral and service sectors. It involved 9 POs (People's Organizations), totalling 46 households. The name of POs and their locations are listed in the Table 1. For each PO, the application of the Wealth Ranking Method chose principally five households ${ }^{3)}$, and detailed interviews with PO managers were conducted.

Finally, a standardized RMM was developed during the course of the exercise of Project Cycle Management (PCM) involving Problem Analysis and Objective Analysis. Through these exercises, a management agenda was identified and incorporated into the RMM. Voting by PO members further enabled the prioritization of action components for the effective management of natural resources.

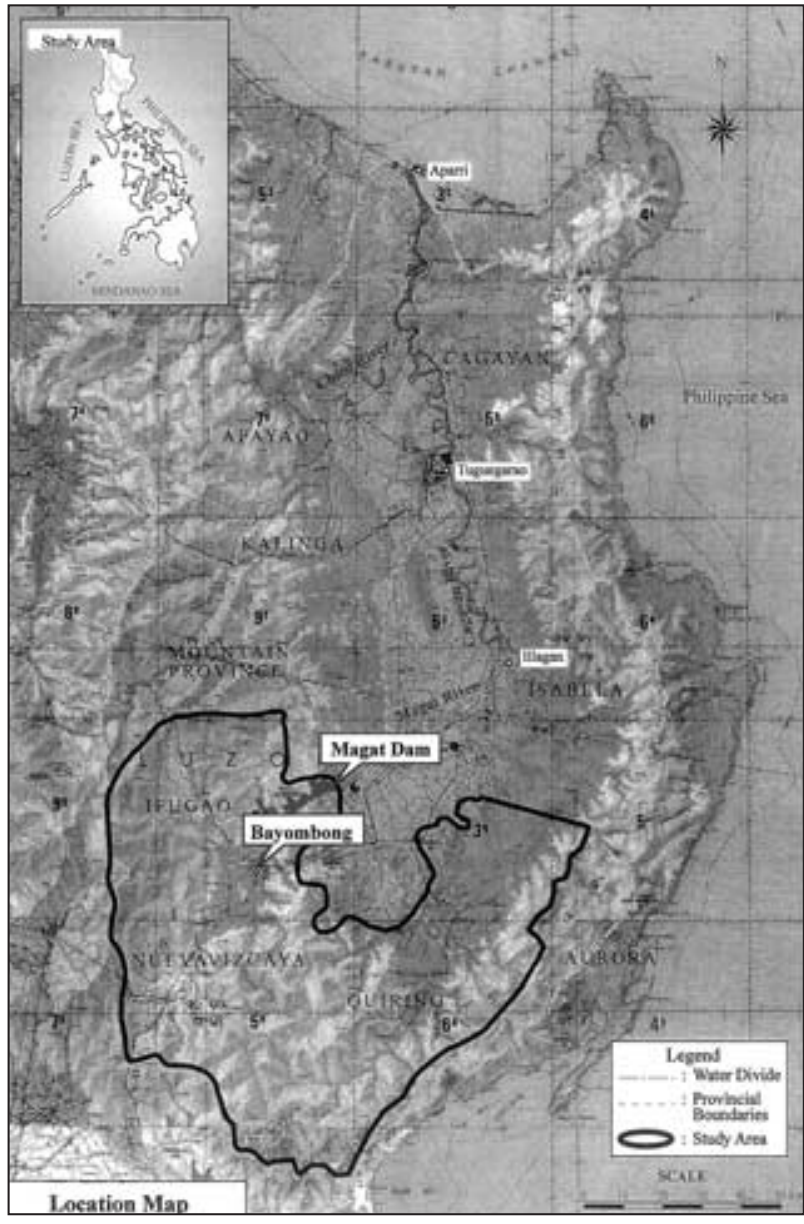

Fig. 1. Location map of the study area in the Philippines.

Table 1. List of POs selected for the field survey.

\begin{tabular}{|c|c|c|c|}
\hline Name of PO/ Province & Barangay & Municipality & $\begin{array}{l}\text { Responsible } \\
\text { CENRO }^{4}\end{array}$ \\
\hline \multicolumn{4}{|l|}{ Nueva Vizcaya } \\
\hline Yaway Farmers Multi-Purpose Cooperative Inc. & Yaway & Aritao & Aritao \\
\hline $\begin{array}{l}\text { Federation of Vista Hills, Kakongkong and } \\
\text { Kakilingan Upland Farmers }\end{array}$ & Buena Vista & Bayombong & Bayombong \\
\hline $\begin{array}{l}\text { J. V. Greeners Tree Planters Association Inc. } \\
\text { Quirino }\end{array}$ & Lublub & Alfonso Castañeda & Dupax \\
\hline Ilongot Livelihood Association Inc. & Landigan & Nagtipunan & Nagtipunan \\
\hline Nuh-uh-uhhaan Inc. & Asaklat & Nagtipunan & Nagtipunan \\
\hline Baguio Village Intercultural Association & Baguio Village & Diffun & PENRO Quirino \\
\hline \multicolumn{4}{|l|}{ Ifugao } \\
\hline Hapid Agro-forestry Developers Association Inc. & Hapid & Lamut & Lamut \\
\hline Mayoyao Environment Development Association Inc. & Mayoyao & Mayoyao & Alfonso Lista \\
\hline Nunhabatan Greeners Livelihood Association Inc. & Hapid & Lamut & Lamut \\
\hline
\end{tabular}

2) These surveys were based on: 1) Interviews with Chairmen and/or Managers of the People's Organizations (POs) responsible for the CBFM program; 2) Interviews with selected PO members; and 3) Site visits to areas where management was conducted through plantation, agroforestry and other management techniques.

3) Based on discussions with PO managers, the basic economic structure was gauged by classifying the PO populations into three relative wealth rankings: 1) Well off, 2) Median and 3) Poorer economic classes. Based on this classification, five households were then chosen corresponding to the relative wealth structure of the PO. Such sampling procedure aimed at not so much grasping precisely the representative picture of the studied POs, as presenting a relative tendency and orientation on the given subjects. By choosing five households, a comparative analysis was made possible among nine selected POs.

4) CENRO signifies Community Environment Natural Resource Office, DENR's branch office at municipality level. CENRO also refers to Community Environment Natural Resource Officer, the head of the Community Environment Natural Resource Office. 


\section{RESULTS AND DISCUSSIONS}

\section{Reviewed CBFM Program in the Philippines}

In the Philippines a number of people-oriented programs started to develop in the 1970s. These programs included Forest Occupancy Management, Family Approach to Reforestation, and Communal Tree Farm. In the 1980s, Integrated Social Forestry (ISF) Program was introduced. All these programs have now been unified and incorporated into the CBFM program, under the Administrative Order No. 96-30 of the Department of Environment and Natural Resources (DENR), which integrated all people-oriented forestry programs and projects into the DENR's regular governance ${ }^{5}$.

The CBFM program was adopted as a national strategy for sustainable management of the country's forestlands with the issuance of Executive Order No.263 on July 9, 1995. It aimed to develop, protect and conserve the existing resources in the delineated forestlands, with management rights awarded to the residing organized populations. The CBFM program gave upland communities located within the forestlands the right to manage the natural resources located in areas specified by the CBFM agreement. About 20 million upland dwellers in the Philippines may be potentially covered by the CBFM agreement to secure their land tenure. The CBFM agreement is reached between DENR and PO and has duration of 25 years, renewable for another 25 years $^{6}$.

The 1987 Constitution of the Philippines classified lands of the public domain into four categories: 1) Agricultural Lands, 2) Forest or Timber Lands, 3) Mineral Lands and 4) National Parks ${ }^{7}$. Under these categories the CBFM program applies to forestlands. According to PD705 ${ }^{8)}$, known as Revised Forestry Code of the Philippines, lands of the public domain with a slope of more than $18 \%$ are regarded as forestlands ${ }^{9}$. Further, CBFM also applies to zones within protected areas designated under NIPAS Act ${ }^{10)}$ As such, the CBFM program has integrated all previous people-oriented forestry approaches, including Integrated Social Forestry (ISF) Program, Community Forestry Program, Coastal Environment Program, and Ancestral Domains recognition program.

As of the first quarter of 2000, a total of 4,828 CBFM sites were established nationwide. These sites covered an aggregate area of 5,338,080 ha involving 425,352 households. There were 2,013 POs consisting of 308,362 households, organized under the CBFM. Of these, 550 agreements were issued by CBFM covering 762,516 ha, consisting of 81,135 households $^{11}$. Within the study area, there were a total of 58 CBFM agreements as of May 2001, covering an area of 101,134 ha, which occupies $5.02 \%$ of the total land area of the four concerning provinces and a region, as shown in Table 2.

Table 2. Areas covered under CBFM agreement in Provinces/Region encompassing the study area.

\begin{tabular}{lrrr}
\hline Province/Region & Total Land Area (ha) & Area under CBFM (ha) & $\%$ \\
\hline \hline N. Vizcaya (province) & 390,387 & 10,401 & 2.66 \\
Quirino (province) & 305,720 & 38,649 & 12.64 \\
Isabela (province) & $1,066,456$ & 45,562 & 4.27 \\
Ifugao (region CAR) & 251,778 & 6,522 & 2.59 \\
Total & $2,014,341$ & 101,134 & 5.02 \\
\hline
\end{tabular}

Within the study area there existed 38 CBFM projects, extending 59,303 ha which accounts for $6.74 \%$ of the total study

5) One of the Philippines's important initiatives in introducing people-oriented forestry was the Integrated Social Forestry (ISF) Program. It was formally launched in 1982 to respond to the needs of the upland dwellers. It aimed to provide the upland farmers with tenure security while promoting ecologically sound farming practices. Under this program two forms of certificates were issued: 1) Certificate of Stewardship Contract (CSC) awarded to individual household; and 2) Certificate of Community Forestry Stewardship (CCFC) awarded on a collective basis to the community. Both CSC and CCFC are tenurial instruments issued within the forestlands. CSC has a duration of 25 years renewable for another 25 years. The title is awarded to individuals or families occupying portions of forestlands. While adoption of agroforestry methods has been mandatory under CSC, it is not a requirement under CCFC, as long as 30 $\%$ of the project area is covered with either forest or fruit tree species. Matters pertaining to the administration of CSC under ISF have now been transferred from DENR to Local Government Units (LGUs).

6) Individual land tenure within a CBFM area is still permitted subject to the approval of PO members, by continued issuance of Certificate of Stewardship Contract (CSC).

7) Article XII, Sec 3 of the Constitution of the Philippines.

8) Presidential Decree No. 705 issued 19 May 1975.

9) Hence, forestlands do not refer to those areas with forest coverage. They are areas in which forest coverage and subsequent resource use have been considered appropriate as a land use strategy due to slope conditions.

10) NIPAS Act (RA 7586): An Act Providing for the Establishment and Management of National Integrated Protected Areas System, Defining its Scope and Coverage, and for Other Purposes, June 1, 1992.

11) DENR internal document. Briefing Material and Status of CBFM Project Implementation in Regions CAR and 2. 
area of 879,958 ha. These projects benefited 3,932 households, equivalent to the population of $24,260{ }^{12}$. The area each member was theoretically responsible for management varied greatly. The average management size per member was the largest in Quirino with 28.36 ha per member, followed by 15.29 ha in Isabela and 10.39 ha in Nueva Vizcaya. The management size per member was the smallest in Ifugao ${ }^{13)}$ at 4.42 ha. Among POs within the study area, the largest was that managed by Wasid Ilongot Tribes Association, which had 6,420 ha with 59 members (108.81 ha per member). The smallest area managed per person was that of Mabasa Tree Planters \& Growers Association, Inc. in Nueva Vizcaya, which had 0.80 ha per member.

\section{Findings from the Survey}

\section{(1) Land Tenure}

The average area under land tenure of the 46 households studied was 4.22 ha per household ${ }^{14)}$. Table 3 shows the results of land tenure size. $39.13 \%$ of the population held 1-3 ha land, followed by $21.74 \%$ of $3-5$ ha. $17.39 \%$ of them held $0-1$ ha of land. Overall, $78.26 \%$ of the studied households had under 5 ha of land.

$80.00 \%$ of the studied households held land under some form of legal tenure. The remaining $20.00 \%$ occupied land without any type of legal instruments. Yet, $55.56 \%$ of the people in this

Table 3. Land holding size among the studied households (H.H.).

\begin{tabular}{crr}
\hline Land size (ha) & Number of H.H. & $\%$ \\
\hline \hline $0-1$ & 8 & 17.39 \\
$1-3$ & 18 & 39.13 \\
$3-5$ & 10 & 21.74 \\
$5-10$ & 6 & 13.04 \\
$10-$ & 4 & 8.70 \\
\hline Total & 46 & 100.00 \\
\hline
\end{tabular}
category possessed land under the Muyong ${ }^{15)}$ system. Of the rest, $22.22 \%$ and $11.11 \%$ held land under declaration and recognition, respectively. The declaration and recognition of land are respected by the community members under conventional land tenure systems. Hence, only one household (2.22\%) of the total respondents was without any type of legal or traditional land tenure ${ }^{16)}$.

Among the 36 households possessing some form of legal instruments, $8.33 \%$ possessed land under private ownership known as A\&D (Alienable and Disposable). $58.33 \%$ held a Certificate of Stewardship Contract (CSC) under Integrated Social Forestry (ISF) program. $27.78 \%$ held land covered under a CBFM agreement without individual tenure. $11.11 \%$ had land under Certificate of Ancestral Domain Claims (CADC) also without individual tenure. One household possessed a 6-ha property with legal tenure based on a pasture lease agreement. The average size of the CSC and A\&D areas was 3.66 ha and 1.73 ha, respectively. Although the CBFM area is managed on a collective basis, individual tenure by each household is recognized. Hence, the actual land use of each household pertaining to the PO in the management of CBFM is largely of an individual nature.

\section{(2) Land Use}

Actual land uses among the studied households were divided into 1) Primary forest, 2) Secondary forest (Residual forest), 3) Grassland and 4) Cleared land. Of the total area of 187.54 ha held by 44 household holdings, $58.37 \%$ was comprised of cultivation, followed by $20.45 \%$ of secondary forest, $14.86 \%$ of grasslands and $6.32 \%$ of primary forest. The cleared lands were classified into those under 1) agroforestry, 2) vegetable farming, 3) tree plantation, and 4) rice paddy. The data were available from 37 households, amounting to a total of 93.46 ha of cleared land. On average, $50.03 \%$ was appropriated for agroforestry, $23.32 \%$ for vegetable growing, $17.65 \%$ for plantation without interplanting fruit trees or vegetables, followed by $9.00 \%$ for rice paddy.

\section{(3) Economic Revenue Analysis}

\section{a. Revenues from Staple Crops, Vegetables and Fruit Productions}

Subsistence farming was prevalent among the upland farmers of the study area. Yet, a substantial interest existed in income

12) The average size of a median household was estimated at 6.17 people per occupying unit in Cagayan Valley, as per data derived from 2001 Philippine Statistical Yearbook (p1-4, p1-33); 2,756,000(The pop. of Cagayan Valley)/446,839(\# of H.H)=6.17.

13) While Nueva Vizcaya, Quirino and Isabela constitute a Province pertaining to Region 02 of administrative boundary of the country, Ifugao is classified as a Cordillera Autonomous Region (CAR) due to its historical autonomous background. Yet all of these administrative units within the Study Area will be described as provinces for convenience in comparative analysis.

14) The largest holder had over 29 ha of land in Mayoyao among members of the Mayoyao Environment Development Association Inc. Out of the 29 ha, 28 ha were held under the Muyong system inherited from the holder's grand parents. The smallest holding was 0.15 ha, declared by Ifugao, also located in Mayoyao. In this case, although the holding size is small, it could be expanded since he can declare more land held by cultivation.

15) Muyong is a piece of natural forest traditionally set aside, protected, owned and inherited by individual households among the Ifugao. They are normally established above the established rice terraces to safeguard the watershed and to provide stable water supply for rice production.

16) The interviewee was a tenant of 0.3 ha of land working as a sharecropper. 
generating opportunities. The following is an analysis of revenues obtained from a number of sources. Agriculture revenues were classified into those obtained from: 1) staple crop production, 2) vegetable production, and 3) fruit production. The revenues from staple crops production included those from upland rice and corn, which generated PHP 44,064 (13.70 \%) and PHP 277,570 (86.30\%), respectively ${ }^{17}$. The production of upland rice was mainly for family consumption. Compared to rice production, more households were involved with corn sales.

There were 28 species of vegetables, mostly grown for family consumption. Yet, the revenue of PHP 441,086 surpassed the staple crops revenue of PHP 321,634. Two crops, sweet peas and Baguio beans, comprised half of all economic revenues 18). Among the 21 species of fruit crops, 11 species generated revenues, equivalent to $52.38 \%$ of the total revenue. Like the other two categories, the majority of the fruit species were used for family consumption, rather than being sold. Lack of an appropriate system for fruit collection, storage, transportation and marketing was observed. The revenue from fruit growing, PHP 60,080, was significantly smaller than those obtained from staple crops and vegetable cultivation. Furthermore, two thirds, or $67.33 \%$, of such revenues were derived from banana. Other fruits were less important, such as Papaya (8.12\%), Mandarin (7.99\%), Peanut (5.83\%) and Pineapple (4.16\%).

This means that in spite of present policies promoting fruit species planting under agroforestry systems (mango, avocado, jackfruit, coconut and guava), no or marginal revenues have so far been attained from such products. A sum of PHP 822,800 was obtained from the revenues of the above three categories, of which $53.61 \%$ was obtained from vegetables sales, and $39.09 \%$ from rice and corn. A minor percentage of $7.30 \%$ was from selling fruits.

Table 4 compares the revenues from vegetables and staple crops to those from fruits. It clearly shows that the less the POs were dependent on fruits sales, the higher the revenues they attained in overall agricultural production sales. For example, Yaway, Ilongot and Vista Hills POs were the least dependent on fruit and gained the highest economic revenues from agricultural activities. Likewise, those POs over $10 \%$ dependent on fruit, such as JV Greeners, Baguio Village and Nuruh-uhhaan POs were among the lowest earning organizations. These findings suggest that the promotion of planting fruit trees for land tenure and forest restoration strategies fails to increase the POs' income.

Table 4. Staple crops and vegetables vs. fruits revenues $(n=46)$

\begin{tabular}{|c|c|c|c|c|c|}
\hline \multirow{2}{*}{ PO Name } & \multirow{2}{*}{$\begin{array}{l}\text { Staple crops } \\
\text { and PHP }\end{array}$} & \multirow{2}{*}{$\begin{array}{c}\text { Vegetables } \\
\%\end{array}$} & \multicolumn{2}{|c|}{ Fruits } & \multirow{2}{*}{$\begin{array}{l}\text { Total } \\
\text { PHP }\end{array}$} \\
\hline & & & IP & $\%$ & \\
\hline Yaway Farmers Multi-Purpose Coop. & 199,050 & 100.00 & 0 & 0.00 & 199,050 \\
\hline Ilongot Livelihood Association Inc (ILAI) & 138,500 & 100.00 & 0 & 0.00 & 138,500 \\
\hline Vista Hills Upland Farmers Association & 189,800 & 98.88 & 2,150 & 1.12 & 191,950 \\
\hline Nunhabatan Greeners Livelihood Assn & 104,835 & 97.10 & 3,130 & 2.90 & 107,965 \\
\hline Mayoyao Env. Dev. Association (MEDAI) & 8,625 & 96.64 & 300 & 3.36 & 8,925 \\
\hline Hapid Agroforestry Developers (HADAI) & 21,450 & 95.97 & 900 & 4.03 & 22,350 \\
\hline JV Greeners Tree Planters Association & 26,316 & 89.77 & 3,000 & 10.23 & 29,316 \\
\hline Baguio Village Intercultural Association & 68,594 & 89.44 & 8,100 & 10.56 & 76,694 \\
\hline Nuh-uh-uhhaan Inc. & 5,550 & 11.55 & 42,500 & 88.45 & 48,050 \\
\hline Total & 762,720 & 92.70 & 60,080 & 7.30 & 822,800 \\
\hline
\end{tabular}

\section{b. Service Sector Revenues}

Table 5 shows revenues derived from the service sector. Among these categories, the largest segment came from public service employment $\left(47.21 \%{ }^{19}\right)$, followed by small business $\left(13.63 \%{ }^{20)}\right)$, and private employment $(12.42 \%)$. Public works included employment opportunities under various government projects ${ }^{21}$. Farm labor included providing work at others' farms for a daily

17) The combined economic values, as well as those appeared in the discussions, are largely indicative, used to conduct comparative analysis among revenue sources. The value itself may not represent a substantial meaning.

18) The revenue of a specific crop was derived by determining whether or not; 1) the crop was produced during the past year, 2) any portion of the crop was sold during the period, as well as finding out; 3 ) the volume of sales measured usually in sacks converted into kilograms, and 4) the unit price sold per kilo. The revenue was calculated by multiplying the unit price by the volume in kilogram.

19) Public servants included public school teachers, civil servants at barangay office and utility services and an operator of community-run rice mill.

20) Small business included a sari-sari store, an agricultural crop intermediary and a tricycle transport service.

21) These included employment in road construction, dam project, road maintenance and other services under various projects including the CASECNAN infrastructure project and RP-German funded projects. Furthermore, private employment included a store and a company honorarium. Family assistance included financial support from family members, including remittance from overseas workers. 
wage $^{22)}$. The public sector provided a significant cash earning means. Financial support from family members, as an independent category within the service sector, did not play a significance role.

Table 5. Revenues from the service sector $(n=46)$

\begin{tabular}{ccccccccc}
\hline Category & $\begin{array}{c}\text { Public } \\
\text { works }\end{array}$ & $\begin{array}{c}\text { Reforest. } \\
\text { project }\end{array}$ & $\begin{array}{c}\text { Public } \\
\text { servants }\end{array}$ & $\begin{array}{c}\text { Private } \\
\text { emplymt }\end{array}$ & $\begin{array}{c}\text { Small } \\
\text { business }\end{array}$ & $\begin{array}{c}\text { Farm } \\
\text { labor }\end{array}$ & $\begin{array}{c}\text { Family } \\
\text { assistance }\end{array}$ & Total \\
\hline \hline PHP & 94,000 & 20,013 & 410,388 & 108,000 & 118,500 & 88,750 & 29,600 & 869,251 \\
$\%$ & 10.81 & 2.30 & 47.21 & 12.42 & 13.63 & 10.21 & 3.41 & 100.00 \\
\hline
\end{tabular}

\section{c. Summary of Economic Revenues Analysis}

Table 6 summarizes the above analysis on economic revenues during the year from April-May 2000 to April-May 2001 of the 46 households studied. The average yearly revenue per household was PHP 41,325.98, or PHP 3,443.83 per month ${ }^{23)}$. The highest earning sector was services, which occupied $45.73 \%$ of all revenues, followed by agriculture (43.12\%) and livestock $(11.15 \%)$. Some observations can be made from these results. The agriculture and service sectors generated similar amounts of revenues. Yet, those POs attaining higher revenues by agriculture depended less on the service revenues. For example, the two highest agriculture revenue earners, Yaway Farmers and Vista Hills Pos, gained no or marginal revenues from the service sector. Among Vista Hills PO members, no revenue was derived from services. The finding indicates that healthy development of commercial agriculture requires less employment opportunities in the service sector.

Table 6. Summary of economic revenues $(n=46)$

\begin{tabular}{lrrrrrrr}
\hline \multicolumn{1}{c}{ PO Name } & \multicolumn{2}{c}{ Agriculture } & \multicolumn{2}{c}{ Livestock } & \multicolumn{2}{c}{ Service } & Total \\
& PHP & \multicolumn{1}{c}{$\%$} & \multicolumn{1}{c}{ PHP } & \multicolumn{1}{c}{ \% } & PHP & \% & PHP \\
\hline \hline Yaway Farmers Multi-Purpose Coop. & 199,050 & 90.95 & 13,800 & 6.31 & 6,000 & 2.74 & 218,850 \\
Vista Hills Upland Farmers Association & 191,950 & 88.27 & 25,500 & 11.73 & 0 & 0.00 & 217,450 \\
Baguio Village Intercultural Association & 73,694 & 66.82 & 0 & 0.00 & 36,600 & 33.18 & 110,294 \\
Ilongot Livelihood Association Inc. & 138,500 & 53.54 & 37,500 & 14.50 & 82,700 & 31.97 & 258,700 \\
Nunhabatan Greeners Livelihood Association & 107,965 & 44.39 & 51250 & 21.07 & 84,000 & 34.54 & 243,215 \\
Hapid Agroforestry Developers & 22,350 & 25.30 & 24,795 & 28.07 & 41,200 & 46.64 & 88,345 \\
Nuh-uh-uhhaan Inc. & 48,050 & 20.01 & 4,900 & 2.04 & 187,188 & 77.95 & 240,138 \\
JV Greeners Tree Planters Association & 29,316 & 7.90 & 18,000 & 4.85 & 323,850 & 87.25 & 371,166 \\
Mayoyao Env. Dev. Association & 8,925 & 5.84 & 36,200 & 23.69 & 107,713 & 70.48 & 152,838 \\
\hline Total & 819,800 & 43.12 & 211,945 & 11.15 & 869,251 & 45.73 & $1,900,995$ \\
\hline
\end{tabular}

\section{(4) Main Interests in the CBFM Program}

Table 7 shows the reasons PO members participated in the CBFM program. Participation in the CBFM occurred voluntarily $(71.43 \%)$ rather than being obliged. Because of disparate numbers of obtained data, a direct comparison of percentages was not feasible. Yet, all interviewed members of Nunhabatan Greeners Livelihood Association and Mayoyao Environment Development Association confirmed their voluntary participation in the CBFM program initiated by the reforestation project. The main interests for participation were divided into three beneficial categories: 1) Land tenure benefits, 2) Economic benefits and 3) Environmental benefits. Although these interests are mutually related, the selection among these options should represent the priorities of the respondents ${ }^{24}$. Curiously, 21 households corresponding to $50 \%$ of the studied population supported each interest.

On the other hand, any one of those interests should outweigh the others depending on the practical needs of each PO

22) In Mayoyao for example, a farm laborer was commonly paid PHP100-120 per day. Aside from cash payment, the provision of labor in exchange for a share of the harvest was also observed in POs such as Yaway Farmers Multi-Purpose Cooperative and Mayoyao Environment Development Association. They worked other families' rice paddies in exchange for receiving half of the harvest volume. Further in Mayoyao, barter transactions were commonly practiced when cash income was limited. The planting was sometimes done within private holdings by contracted labor available within the community at a rate of PHP150 per day.

23) This was equivalent to yearly and monthly revenues of JPY 99,182, and JPY 3,443, respectively, at PHP=Yen 2.40 , the approximate exchange rate during the field survey period.

24) Because of the interrelated nature of the answers, multiple choices were allowed. 
participating in the CBFM program. Such presumption was endorsed by further analysis. Despite the curious coincidence of each interest having equal significance, the priority ranking varied among all nine POs. In Table 7, the names of POs are listed from most priority of interest given to land tenure under the CBFM to least priority. All respondents of Vista Hills Upland Farmers Association confirmed land tenure as the highest priority, while merely one respondent rated the environmental conservation role of the CBFM program as the number one priority. A correlation was found between land tenure and economic benefits. Those POs interested mainly in land tenure tended to recognize a minor degree of interest in economic benefits, and vice versa.

Table 7. Main interests in participating in the CBFM program.

\begin{tabular}{|c|c|c|c|c|c|c|c|c|c|c|}
\hline \multirow[b]{2}{*}{ PO Name } & \multirow[b]{2}{*}{$\begin{array}{c}\text { Voluntary } \\
\text { Participation } \\
\end{array}$} & \multirow[b]{2}{*}{ n. } & \multirow[b]{2}{*}{$\begin{array}{l}\text { Total } \\
\text { H.H. }\end{array}$} & \multicolumn{7}{|c|}{ Main Interest in CBFM } \\
\hline & & & & $\begin{array}{c}\text { Land } \\
\text { Tenure }(\%) \\
\end{array}$ & n. & $\begin{array}{l}\text { Environment } \\
\text { Concern }(\%) \\
\end{array}$ & $\mathrm{n}$. & $\begin{array}{c}\text { Economic } \\
\text { Interest }(\%) \\
\end{array}$ & n. & $\begin{array}{l}\text { Tota } \\
\text { H.H. }\end{array}$ \\
\hline Vista Hills Upland Farmers Assn & 75.00 & 3 & 4 & 100.00 & 5 & 0.00 & 0 & 20.00 & 1 & 5 \\
\hline Baguio Village Intercultural Assn & 66.67 & 2 & 3 & 80.00 & 4 & 20.00 & 1 & 20.00 & 1 & 5 \\
\hline Nuh-uh-uhhaan Inc. & 25.00 & 1 & 4 & 60.00 & 3 & 100.00 & 5 & 60.00 & 3 & 5 \\
\hline Yaway Farmers Multi-Purpose Coop. & 75.00 & 3 & 4 & 50.00 & 2 & 50.00 & 2 & 25.00 & 1 & 4 \\
\hline Ilongot Livelihood Association & 100.00 & 1 & 1 & 40.00 & 2 & 40.00 & 2 & 60.00 & 3 & 5 \\
\hline Nunhabatan Greeners Livelihd Assn & 100.00 & 5 & 5 & 40.00 & 2 & 80.00 & 4 & 60.00 & 3 & 5 \\
\hline JV Greeners Tree Planters Assn & 40.00 & 2 & 5 & 25.00 & 1 & 50.00 & 2 & 50.00 & 2 & 4 \\
\hline Mayoyao Env. Development Assn & 100.00 & 4 & 4 & 25.00 & 1 & 75.00 & 3 & 75.00 & 3 & 4 \\
\hline Hapid Agroforestry Dev. Assn & 80.00 & 4 & 5 & 20.00 & 1 & 40.00 & 2 & 80.00 & 4 & 5 \\
\hline Total & 71.43 & 25 & 35 & 50.00 & 21 & 50.00 & 21 & 50.00 & 21 & 42 \\
\hline
\end{tabular}

In addition, an interesting observation was made about the above results in comparison to the results on economic revenues summarized in Table 6. The smaller the revenues the POs derived from agriculture, the more interest was shown in economics as a reason participating in the CBFM program. For example, Mayoyao Environment Development Association and Hapid Agroforestry Developers were the lowest agriculture revenue earners, and they expressed the highest level of interest in economic income for participating in the CBFM. Likewise, the highest agricultural revenue earners, Yaway Farmers Multi-Purpose Coop. and Vista Hills Upland Farmers Association were among those who showed the least interest in economic income for participating in the program. Such results showed that those POs unable to earn enough revenues with agriculture depended on other revenue sources, principally from the service sector, and demonstrated a desire to increase income opportunities through participation in the CBFM program.

\section{(5) Constraints on Sustainable Forest Management}

In order to identify constraints in the execution of the CBFM program, the entirety of the Community Resource Management Framework (CRMF), which is a management plan for implementation of the CBFM program, was reviewed and analysed. Main constraints included a lack of: 1) training for human resource development, 2) basic infrastructure, including water supply facilities and 3) forest protection against fires. Necessary training includes training for financial management and bookkeeping, organizational management, forest management and law enforcement, upland farm management technology and marketing, in addition to enterprise and business development. Necessary infrastructure includes roads, electrification, water supply and communication tools. Fire posed a leading threat to successful management of forestlands. Rampant fires broke out both accidentally and intentionally under inappropriate Kaingin (slash-and-burn) and pasture practices, wasting reforestation efforts.

The above constraints documented in the CRMF were further verified by conducting a field survey and the results are summarized in Table 8. The identified problems were related to: 1) Plantations such as lack of funds for plantation and maintenance, as well as fires; 2) Timber harvesting, such as timber poaching and delayed harvest permission; 3) Community organizing and strengthening; 4) Livelihood, such as lack of livelihood means and delayed payment of contracted labor under reforestation projects; 5) Natural conditions, such as lack of water supply and unfertile soil in some CBFM areas; and 6) Administration policies, such as the inadequate size of some CBFM areas.

Altogether $45.00 \%$ of the respondents identified some kind of problem concerning the execution of the CBFM program. 
As shown in Table 8, responses varied greatly among the POs studied. All interviewed members from three POs; Vista Hills Upland Farmers Association, Ilongot Livelihood Association and Mayoyao Environment Development Association had no problems. On the other hand, all the respondents of Nunhabatan Greeners Livelihood Association and Nuh-uh-uhhaan Inc. affirmed the existence of problems. Identified problems were classified into the following five categories, which were then processed and incorporated into the RMM. The identified problems, however, were concerned more with practical applications, rather than the fundamental scheme and structure, of the CBFM framework.

1) Initial Capital

- Lack of funds for plantation establishment and maintenance

2) Human Resources Development

- Insufficient community organizing and PO strengthening;

3) Livelihood Development

- Lack of livelihood income opportunities and delayed payments of contract labor on reforestation projects

4) Forest Protection

- Accidental as well as intentional fire for kaingin (slash-and-burn agriculture) and pasture, in addition to timber poaching

5) Forest Management

- DENR approval on timber harvesting

Table 8. Number of problems facing the CBFM program

\begin{tabular}{|c|c|c|c|c|c|c|c|c|}
\hline PO Name & n. & Plantation & Harvest & $\begin{array}{c}\text { Commty } \\
\text { Org }\end{array}$ & $\begin{array}{l}\text { Livelihood } \\
\text { Means }\end{array}$ & $\begin{array}{c}\text { Natural } \\
\text { conditions }\end{array}$ & Administration & Total \\
\hline Nuh-uh-uhhaan Inc. & 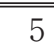 & & 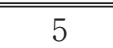 & & & & & 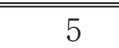 \\
\hline Nunhabatan Greeners Livelihood Assn & 4 & 2 & & & 1 & 1 & & 4 \\
\hline JV Greeners Tree Planters Association & 4 & 1 & & 1 & 1 & & & 3 \\
\hline Hapid Agroforestry Developers Assn & 5 & 2 & & & & & 1 & 3 \\
\hline Baguio Village Intercultural Association & 5 & & & & & 1 & 1 & 2 \\
\hline Yaway Farmers Multi-Purpose Coop. & 4 & & & 1 & & & & 1 \\
\hline Vista Hills Upland Farmers Association & 5 & & & & & & & 0 \\
\hline Ilongot Livelihood Association Inc. & 4 & & & & & & & 0 \\
\hline Mayoyao Env. Dev. Association & 4 & & & & & & & 0 \\
\hline Total & 40 & 5 & 5 & 2 & 2 & 2 & 2 & 18 \\
\hline$\%$ & & $27.78 \%$ & $27.78 \%$ & $11.11 \%$ & $11.11 \%$ & $11.11 \%$ & $11.11 \%$ & $100.00 \%$ \\
\hline
\end{tabular}

Table 9. Number of perceptions on successful CBFM program elements.

\begin{tabular}{cccccc}
\hline PO Name & $\begin{array}{c}\text { Community } \\
\text { orgnzing \& } \\
\text { Good } \\
\text { Leadership }\end{array}$ & $\begin{array}{c}\text { Income \& } \\
\text { Marketing } \\
\text { opportunity }\end{array}$ & $\begin{array}{c}\text { Land } \\
\text { tenure }\end{array}$ & $\begin{array}{c}\text { Processing } \\
\text { of products }\end{array}$ & Total \\
\hline \hline Nuh-uh-uhhaan Inc. & 5 & 5 & 2 & 2 & 14 \\
Baguio Village Intercultural Association & 4 & 0 & 1 & 0 & 5 \\
Hapid Agroforestry Developers Association & 4 & 3 & 1 & 0 & 8 \\
Mayoyao Environment Development Assn & 3 & 3 & 0 & 0 & 6 \\
Nunhabatan Greeners Livelihood Assn & 3 & 4 & 1 & 0 & 8 \\
Vista Hills Upland Farmers Association & 3 & 1 & 2 & 0 & 6 \\
Yaway Farmers Multi-Purpose Coop. & 3 & 3 & 0 & 0 & 6 \\
J V Greeners Tree Planters Assn & 3 & 2 & 1 & 0 & 6 \\
Ilongot Livelihood Association Inc. & 1 & 1 & 2 & 1 & 5 \\
\hline Total & 29 & 22 & 10 & 3 & 64 \\
\% & $45.31 \%$ & $34.38 \%$ & $15.63 \%$ & $4.69 \%$ & $100.00 \%$ \\
\hline
\end{tabular}




\section{(6) Elements for a Successful CBFM Program}

In addition to constraints, basic elements leading to successful CBFM program were examined by an additional survey. Based on the constraints survey results, four principal elements were presumed: 1) Human Resource Development through community organizing and good leadership; 2) Livelihood Development through income and marketing opportunities; 3) Livelihood Development through processing of harvested products; and 4) Basic Infrastructure based on land tenure. The survey results are shown on Table 9.

There were a total of 64 responses, of which $45.31 \%$ replied that community organizing and good leadership were the most important elements for successful CBFM, followed by income and marketing opportunities (34.38 \%), land tenure $(15.63 \%)$ and processing products $(4.69 \%)$. As discussed in the following section on the Resource Management Model, all of these elements belonged to the Management Capital, which serves as the fundamental capital promoting actions related to Natural Resource Management.

\section{Development and Application of the RMM}

\section{(1) Development of a Resource Management Model (RMM)}

Based on these findings on various management requirements, a standardized RMM was developed and applied during the course of designing a pilot study ${ }^{25}$ through the Community Action Planning (CAP). The pilot study was to verify the viability of the drafted Master Plan, and was initiated by selected POs.

Table 10. Revenues from the service sector $(n=46)$

\begin{tabular}{|c|c|c|c|c|c|c|c|}
\hline Name of PO & $\begin{array}{c}\text { CBFM } \\
\text { (ha) }\end{array}$ & $\begin{array}{c}\text { Nature } \\
\text { of } \\
\text { PO }\end{array}$ & $\begin{array}{l}\text { No. of } \\
\text { PO } \\
\text { Members }\end{array}$ & $\begin{array}{c}\text { No. of } \\
\text { Active } \\
\text { PO } \\
\text { Members }\end{array}$ & $\begin{array}{c}\text { Active } \\
\text { Members } \\
\text { Ratio } \\
(\%)\end{array}$ & $\begin{array}{c}\text { Management } \\
\text { Area per } \\
\text { Member } \\
\text { (ha) }\end{array}$ & $\begin{array}{c}\text { Management } \\
\text { Area per } \\
\text { Active } \\
\text { Member } \\
\text { (ha) }\end{array}$ \\
\hline Banila Community-Based Association & 190.00 & Cooperative & 73 & 73 & 100.00 & 2.60 & 2.60 \\
\hline Balligui Community Forestry \& Dev't. Coop. & $1,180.00$ & Cooperative & 74 & 54 & 72.97 & 14.59 & 20.00 \\
\hline Nunhabatan Greeners Livelihood Assn & 241.00 & Association & 50 & 0 & 0.00 & 4.82 & - \\
\hline Ayangan Dapiz Agro-Forestry Dev't Assn & 487.50 & Association & 67 & 0 & 0.00 & 7.28 & - \\
\hline Total & $2,098.50$ & & 264 & 127 & - & - & - \\
\hline Average & 499.63 & & 66 & 32 & 43.24 & 7.32 & \\
\hline
\end{tabular}

Table 10 presents a basic profile of the POs participating in the pilot study. The total CBFM area allotted for the implementation of the pilot study amounted to 2,098.50 ha. Community Action Planning (CAP) involved undertaking PCM, in which Problem Analysis ${ }^{26)}$ and Objective Analysis ${ }^{27)}$ were employed by PO members in order to identify and articulate their problems with the ultimate goal of resolving them. Based on these exercises, an agenda with concrete activities was designed. Analytical classification of the identified management components led to the formulation of the standardized RMM.

The Model identifies two fundamental resources to be managed: Human Resources and Natural Resources. Natural resource management consists of the management of a variety of natural resources within a certain geographical boundary such as that delineated by the CBFM agreement. Natural resources include forest resources, agricultural as well as pastoral resources, water resources, genetic resources and resources for developing eco-tourism with esthetic as well as ethnocultural values. The local population therein is regarded as a human resource. Through the process of human resources development they will become the principal natural resource managers.

The Model assumes that a viable, cost-effective and efficient management of natural resources in a given demarcated area is attained by the mobilization of the human resources therein, through capitalizing themselves as Management

25) The pilot study was conducted as part of the work for the designing the Master Plan for watershed management of upper Magat and Cagayan river basin, conducted by JICA.

26) Problem Analysis is a participatory analytical process for detecting problems and their root causes faced by a group identified by members themselves Through discussions facilitated by a moderator, a variety of concurrent problems faced by the members will be grouped together and organized in a causeand-effect manner into a Problem Tree format, as illustrated in Figure 3.

27) Objective Analysis is a participatory analytical process for determining an appropriate course of action, which will be identified by reversing each situation component of the Problem Tree formulated by the Problem Analysis, through the statement describing the situation if the identified problems were resolved. A group of identified ideal situation components are organized into means- and-effect relationships. Both Problem Analysis and Objective Analysis are used in the Project Cycle Management process. See Research on Rural Community Research Method Reports (in Japanese) prepared by Department of Development Study on Agriculture, Forestry and Fishery, JICA. February 1999. 
Capital, by which actions related to natural resource management would be pursued. Such a resource management approach would integrate the existing human resources into a natural resource management scheme.

Furthermore, the human resources would constitute a Management Capital accompanied by two other prerequisite components: 1) Basic Infrastructure and 2) Livelihood Development, which would support actual mobilization of capitalized human resources. A variety of livelihood development initiatives, such as livestock raising, fish culture or apiculture, have often been regarded as a sideline incentive and/or a supplementary component in pursuing natural resource management. Here in the RMM however, livelihood development is recognized as a vital and indispensable element in resource management initiatives, by way of nurturing the Management Capital furnished by organized and capable human resources. Likewise, basic infrastructure, such as farm-to-market roads, bridges and adequate storage facilities would also constitute a fundamental component of the Management Capital that would enable the effective mobilization of the Natural Resource Management.

Figure 2 illustrates the basic structure of the RMM. It is considered that community forestry as a viable resource management strategy will become effective to the extent in which resource management is pursued following the satisfactory development of the Management Capital.

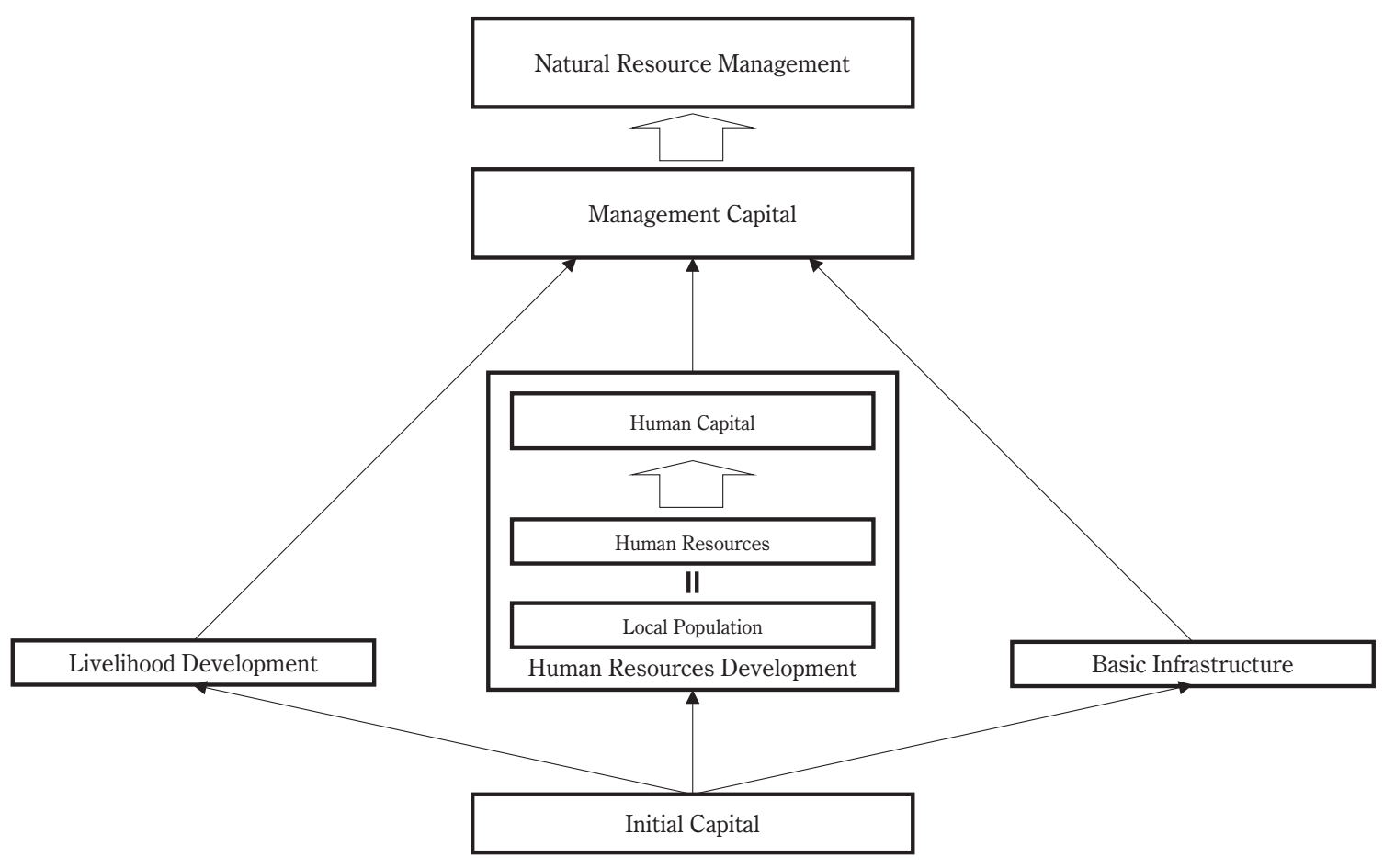

Fig. 2. Structure of a resource management model (RMM).

\section{(2) Application of the Resource Management Model}

Figures 3 and 4 show examples of results from Problem Analysis and Objective Analysis, respectively obtained from one of the pilot study participating POs - Banila Community-Based Association. The elements identified in the Objective Analysis were translated into a series of necessary action agenda in the voting, the results of which are shown in Table $11^{28)}$.

In Table 11 each action was classified into either of the category components constituting the RMM shown in Figure 2, the results of which were further summarized in Table 12 and Figure 5. It can be seen that, including initial capital, about two thirds of the management requirements are concerned with nurturing the Management Capital, while the remaining one third is related to activities of natural resource management itself. The finding suggests that as far as the resource management is concerned, more emphasis should be given to building up the Management Capital than to implementing actual management activities.

28) The survey was conducted by 20 members representing the Coop., allocating each member with 10 choices. Due to counting errors during the exercise, the choices totaled 222 . 


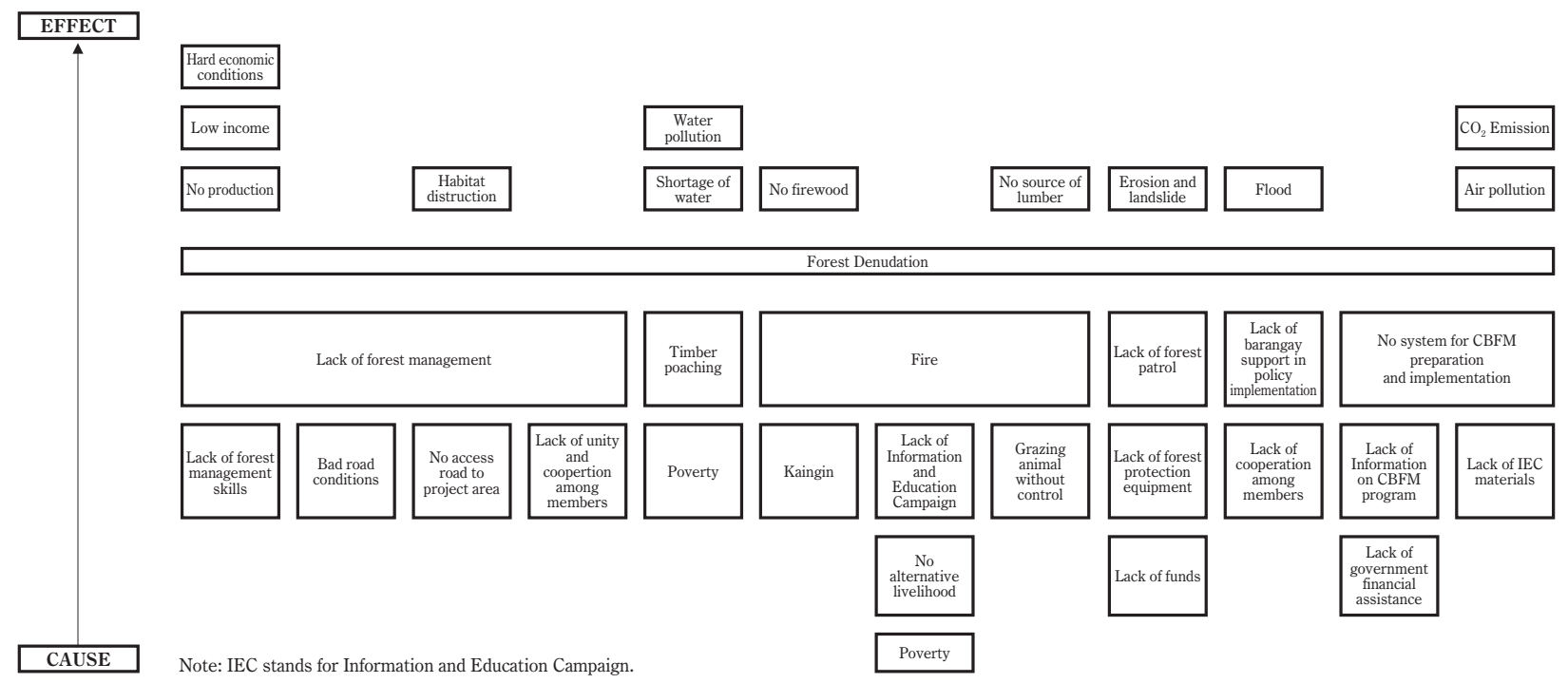

Fig. 3. Problem analysis of banila community-based cooperative Inc.

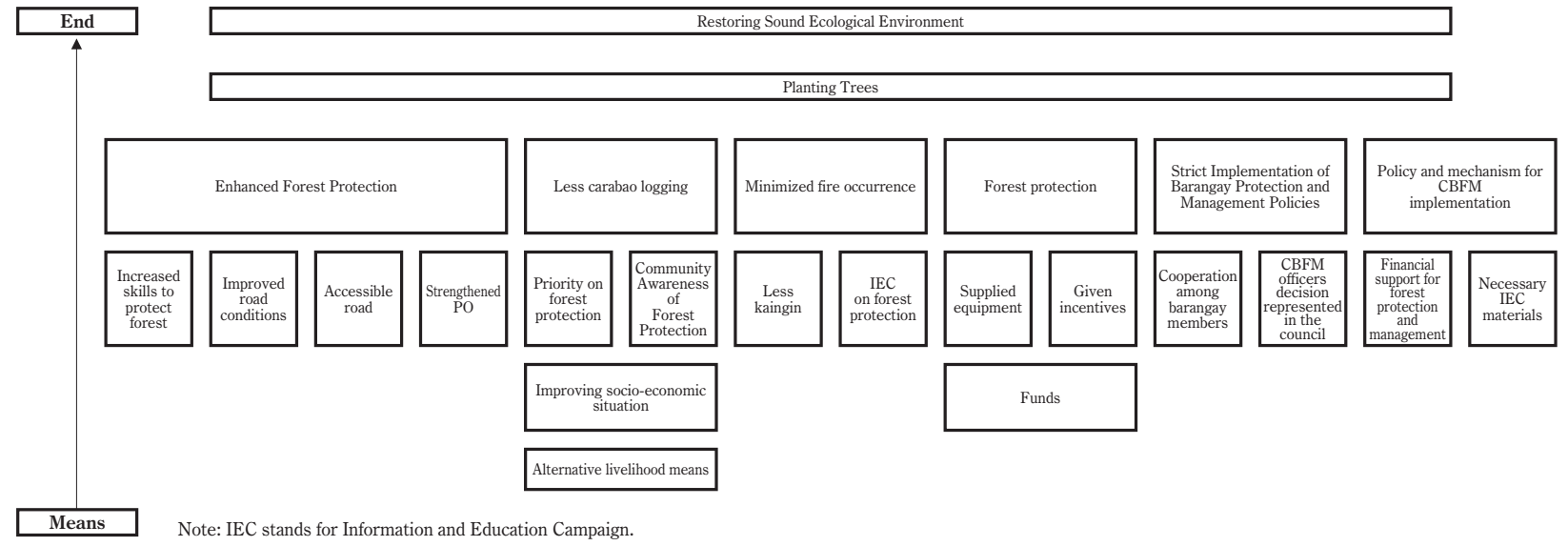

Fig. 4. Objective analysis performed by banila community-based cooperative, Inc.

Table 11. Necessary actions identified by a survey of the banila community-based association.

\begin{tabular}{lccl}
\hline \multicolumn{1}{c}{ Necessary Actions } & Votes & $\%$ & \multicolumn{1}{c}{ Management Category } \\
\hline \hline Funds & 39 & 17.57 & Initial Capital \\
Alternative Livelihoods & 38 & 17.12 & Livelihood Development \\
Tree planting & 37 & 16.67 & Natural Resource. Management \\
Accessible roads & 24 & 10.81 & Basic Infrastructure \\
Upliftment of life & 20 & 9.01 & Livelihood Development \\
Strengthened forest protection & 18 & 8.11 & Natural Resource Management \\
PO Strengthening & 13 & 5.86 & Human Resource Development \\
Rules and Discipline & 12 & 5.41 & Human Resource Development \\
Forest guard & 12 & 5.41 & Natural Resource Management \\
Grazing control & 9 & 4.05 & Natural Resource Management \\
\hline \multicolumn{1}{c}{ Total } & 222 & 100.00 & \\
\hline \multicolumn{1}{c}{} & & &
\end{tabular}


Table 12. Management requirements for the banila community-based association under the resource management model.

\begin{tabular}{lrr}
\hline \multicolumn{1}{c}{ Management Requirements } & Votes & $\%$ \\
\hline \hline 1. Natural Resource Management & 76 & 34.23 \\
2. Management Capital & 107 & 48.20 \\
2.1. Human Resource Development & 25 & 11.26 \\
2.2. Livelihood Development & 58 & 26.13 \\
2.3. Infrastructure & 24 & 10.81 \\
3. Initial Capital & 39 & 17.57 \\
\hline Total & 222 & 100.00 \\
\hline
\end{tabular}

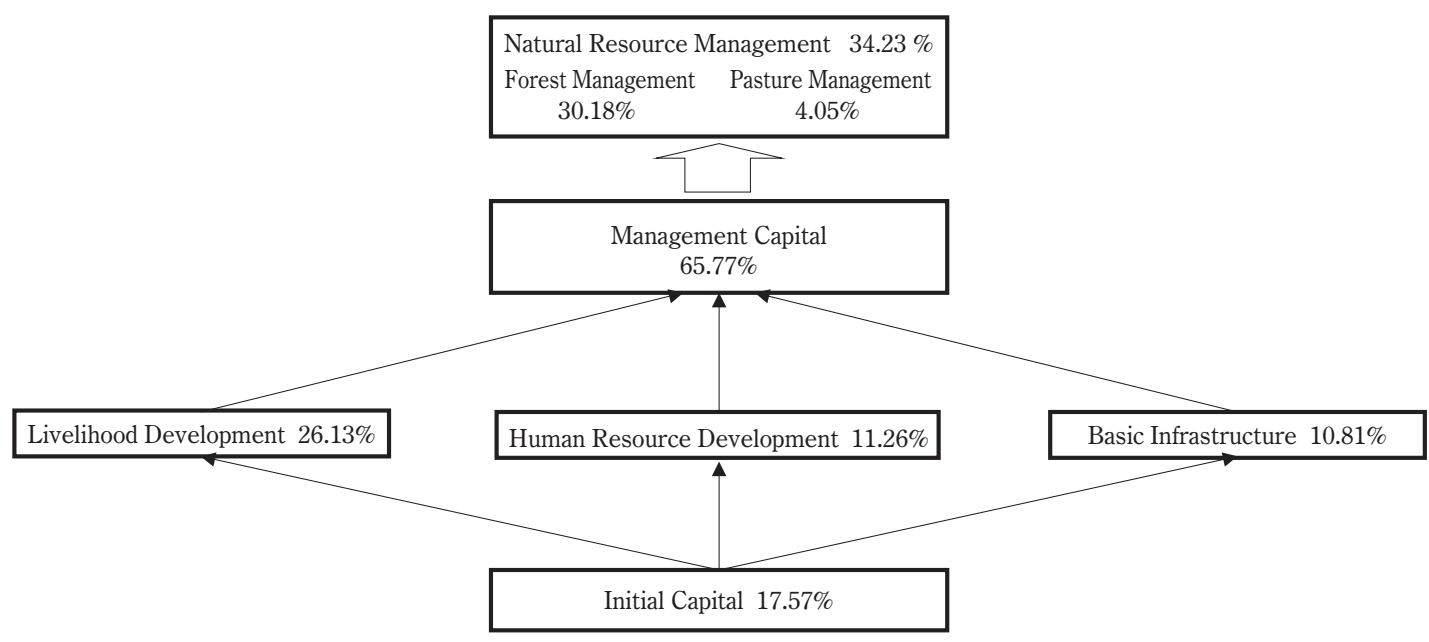

Fig. 5. Resource management model of banila community-based association (Percentage indicates the priority given to each component as identified by the survey.)

Based on the identified management requirements, an action agenda was formulated. Table 13 presents this agenda proposed by POs, as well as the results of gained votes classified in accordance with managerial categories constituting the RMM. This process enabled the management components to be clarified and subsequently strengthened, as illustrated in Table $14^{29}$.

In Table 14, management requirements were classified into two basic management categories: 1) Management Capital, comprising of Human Resource Development, Livelihood Development and Basic Infrastructure; and 2) Natural Resource Management including Forest Protection, Forest Management and Pasture Management ${ }^{30}$. Introducing a line of activities relating to natural resource management is feasible only if the Management Capital is securely built up. The survey results, shown in Table 14, enabled the identification of management components that were perceived necessary by voters to achieve viable natural resource management within the area delineated by the given CBFM program.

The above results show that for viable natural resource management more emphasis should be placed on nurturing the Management Capital for Banila Community-Based Association, as well as for Ayangan Dapiz Agro-Forestry Development Association, than on introducing activities directly related to the management of natural resources. On the other hand, more emphasis on management activities of natural resources was expected both for Balligui Community Forestry and Development Cooperative and Nunhabatan Greeners Livelihood Association, rather than activities directed towards building up the Management Capital. To the extent that the voting was employed to elucidate the prioritization of management requirements, the obtained results identified perceived requirements among the PO members. These findings were further useful for a comparative analysis among the POs to identify which management components should be developed and strengthened first.

29) The results of management requirements for Banila Community-Based Cooperative differed in Table 11 and 12 due to: 1) the change of components included in the action agenda led by a workshop facilitator; 2) the composition change of voters at the workshop and the General Assembly; and 3) the change of opinions of the voters.

30) Variably managed natural resources include flora and fauna and their genetic resources, headwaters, springs and other watersheds, minerals, resources for eco-tourism and landscape with esthetic values. 
Table 13. Results of the survey on the action plan by PO members and categorization of the management components

\begin{tabular}{|c|c|c|c|c|}
\hline Action Agenda & votes & $\%$ & Management Component & Management Category \\
\hline \multicolumn{5}{|l|}{ Banila Community-Based Association Inc. } \\
\hline Provide livelihood alternative to slash-and-burn farmers and carabao loggers & 76 & 19.34 & Livelihood Development & Management Capital \\
\hline Improve existing road and trails going to and within the CBFM area & 87 & 22.14 & Basic Insfrastructure & Management Capital \\
\hline Strengthen the capacity of the $\mathrm{P} 0$ to manage their organization and projects & 76 & 19.34 & Human Resource Development & Management Capital \\
\hline Minimize Forest Fires & 64 & 16.28 & Forest Protection & Natural Resource Management \\
\hline Enhance skills and knowledge on plantation management & 90 & 22.90 & Forest Management & Natural Resource Management \\
\hline Total & 393 & & & \\
\hline \multicolumn{5}{|l|}{ Nunhabatan Greeners Livelihood Association Inc. } \\
\hline Improve organizational cooperation and unity & 62 & 19.68 & Human Resource Development & Management Capital \\
\hline Minimize forest fires & 46 & 14.60 & Forest Protection & Natural Resource Management \\
\hline Improve plantation management within CBFM area & 59 & 18.73 & Forest Management & Natural Resource Management \\
\hline Improve pasture land management & 57 & 18.10 & Pasture Management & Natural Resource Management \\
\hline Total & 224 & 71.11 & & \\
\hline \multicolumn{5}{|l|}{ Balligui Communitry Forestry and Development Cooperative Inc. } \\
\hline Increase sustainability of land use for forestland occupation & 63 & 21.80 & Forest Management & Natural Resource Management \\
\hline Mobilize funds for environmental projects & 59 & 20.42 & Forest Management & Natural Resource Management \\
\hline Improve resource management and protection of remaining forest & 49 & 16.96 & Forest Protection & Natural Resource Management \\
\hline Control migration & 47 & 16.26 & Forest Management & Natural Resource Management \\
\hline Total & 289 & 100.00 & & \\
\hline \multicolumn{5}{|l|}{ Ayangan Dapiz Agro-Forestry Development Association } \\
\hline Improve quality of life to become effective forestland managers & 149 & 31.70 & Livelihood Development & Management Capital \\
\hline Develop leaders and members to become effective forest zone managers & 98 & 20.85 & Human Resource Development & Management Capital \\
\hline Improve enforcement of forest protection policies & 104 & 22.13 & Forest Protection & Natural Resource Management \\
\hline Establish and manage fruit and forest tree plantations & 119 & 25.32 & Forest Management & Natural Resource Management \\
\hline Total & 470 & 100.00 & & \\
\hline
\end{tabular}

Table 14. Management requirements of the POs participating in the pilot study

\begin{tabular}{lccrr}
\hline Management Requirements & $\begin{array}{c}\text { Banila } \\
(\mathbf{\%})\end{array}$ & $\begin{array}{c}\text { Ayangan Dapiz } \\
(\mathbf{\%})\end{array}$ & $\begin{array}{c}\text { Nunhabatan } \\
(\boldsymbol{\%})\end{array}$ & $\begin{array}{c}\text { Balligui } \\
(\boldsymbol{\%})\end{array}$ \\
\hline \hline Management Capital & 60.81 & 52.55 & 48.57 & 24.57 \\
$\quad$ Livelihood Development & 19.34 & 31.70 & 28.89 & 0.00 \\
Basic Infrastructure & 22.14 & 0.00 & 0.00 & 24.57 \\
Human Resource Development & 19.34 & 20.85 & 19.68 & 0.00 \\
Natural Resource Management & 39.19 & 47.45 & 51.43 & 75.43 \\
Forest Protection & 16.28 & 22.13 & 14.60 & 16.96 \\
Forest Management & 22.90 & 25.32 & 18.73 & 66.78 \\
Pasture Management & 0.00 & 0.00 & 18.10 & 0.00 \\
\hline Total & 100.00 & 100.00 & 100.00 & 100.00 \\
\hline
\end{tabular}

ACKNOWLEDGMENTS The author thanks the Department of Agriculture, Forestry and Fisheries Development Study of Japan International Cooperation Agency (JICA) for the authorization given to produce and publish for this journal the results of study conducted during the undertaking of The Master Plan Study for Watershed Management in Upper Magat and Cagayan River Basin in the Republic of the Philippines. I also would like to thank the colleagues of the Study Team, both Japanese and the Philippine counterpart experts, with whom this study was conducted, and without whose excellent skills and expertise the data collection and analysis for this research would not have been possible. 


\section{REFERENCES}

Bisson, J. (ed.) 1997. Mid-Term Assessment of the Forest Resources Management Activity. October - December 1996. USAID project assessment document.

ESSC. 1999. Forest People Facing Change. Learning of the Philippine Working Group on Community Forest Management. Volume No.2. Philippine Working Group. Environmental Science for Social Change (ESSC).

JICA. 2001. The Master Plan Study for Watershed Management in Upper Magat and Cagayan River Basin in the Republic of the Philippines. Interim Report. Volume 1: Main Text, Volume 2: Appendices.

Lynch, O.J. and Talbott, K. 1995. Balancing Acts: Community-Based Forest Management and National Law in Asia and Pacific. World Resources Institute. September, 1995.

Mickelwait, D.R. (ed.) 1999. Community-Based Forest Management at a Crossroads: The Future of Sustainable Forest Management in the Philippines. Prepared for USAID by Development Alternative Inc. under Natural Resource Management Program.

Nagano, Y., Hayama, A., and Seki, Y. 2000. Environment and Community in the Philippines (In Japanese). Akashi Shoten Inc.

Talisayon, S.D. (ed.) 1991. Innovative Development Process in the Philippines. Case Studies. Asian Center. University of the Philippines.

Poffenberger, M. (ed.) 1990. Forest Management Partnerships: Regenerating India's Forests. Executive Summary of the Workshop on Sustainable Forestry. New Delhi 10-12 September, 1990.

Poffenberger, M. et al. (ed.) 1996. Grassroots Forest Protection: Eastern Indian Experinces. Asia Forest Network. Research Network Report. Number 7. March 1996.

Poffenberger, M. (ed.) 1997. Linking Government with Community Resource Management. What's Working and What's Not. A Report of the $5^{\text {th }}$ Asia Forest Network Meeting. Surajkund, India. December 2-6, 1996. Asia Forest Network. Research Network Report. Number 9. May, 1997.

Victor M, Lang, C. and Bornemeier, J. 1997 (ed.). Community Forestry at a Crossroads: Reflections and Future Directions in the Development of Community Forestry. Proceedings of an International Seminar held in Bangkok, Thailand. 17-19 July 1997. Regional Community Forestry Training Center (RECOFTC). 1998.

World Bank. 2000. Alleviating Poverty through Forest Development (India). Evaluation Country Case Study Series.

Received $2^{\text {nd }}$ Dec. 2002

Accepted $3^{\text {rd }}$ July 2003 